\title{
The Power of Humanisation. The Role of Literary Studies and of Kurdish Literature ${ }^{1}$
}

\begin{abstract}
The paper discusses the role of literature and literary studies in the possible humanisation of people representing different cultures. It is based on the results of socio psychological studies on the subtle forms of dehumanisation and on the personal experience of being a representative of minority. Furthermore, the author focuses on Kurdish literature by offering a close analysis of a story by Mehmet Dicle, the Kurdish writer from Turkey. She argues that whereas people have generally a tendency to ascribe less of the so called uniquely human features to the representatives of the outgroups (i.e. to subtly dehumanise others), the access to the inner worlds of others - as expressed through literature - may become an important tool to overcome this dangerous phenomena. It is because the aesthetical aspects of the narratives and the moral imagination they furnish make us more sensitive to the complexity of human choices. Accordingly, paying more attention to the literature of minoritized groups seems of crucial importance for challenging the discriminatory policies and exclusion.
\end{abstract}

Keywords: dehumanisation, moral imagination, literature, Kurdish studies

Inside it, there's a smaller one of undiminished worth.

The second holds a third one the third contains a fourth.

A centripetal fugue. Polyphony compressed.

Wistawa Szymborska ${ }^{2}$

${ }^{1}$ This article is a result of the research project: How to Make a Voice Audible? Continuity and Change of Kurdish Culture and of Social Reality in Postcolonial Perspectives (http://www.kurdishstudies.pl) approved for financing by The National Science Centre of Poland (decision number DEC-2012/05/E/ HS2/03779). The summary of the studies on dehumanisation was first published in my paper entitled $\mathrm{Hu}$ manising the Actors and Working Through The Conflict: The Role of Kurdish Literature and Culture in The Reconciliation Process in Turkey, "International Journal of Conflict and Violence" 2018, no. 12, pp. 1-16.

2 W. Szymborska, from The Onion, trans. by S. Barańczak, C. Cavanagh, http://www.szymborska. org.pl/the-onion.html (access: 30.04.2019). 


\section{Introduction}

While translating, publishing and selling literature is not an easy task these days, especially in case of the titles that represent the outside world of the many distant others, the acute question arises regarding the future of the literary studies. Does literature and literary research really play any role in bridging people, societies and cultures or is it a simple slogan repeated thoughtlessly in many grant applications in order to show their social applicability and justify the costs spent on them? Why should they be supported in times of shortages and growing human needs?

Being the part of the festschrift honouring Professor Anna Krasnowolska whom we owe the great insight into the world of Iranian cultures as well as the beautiful translations of Persian literature into Polish language, my article is designed to explore and highlight the role that the so called "literature of others" may play in our complex and divided modern world. In order to do so I will refer to a few socio psychological theories on the different types of dehumanisation and search for the possible ways we can cope with this phenomena by the means of literature and literary studies.

The dehumanisation is generally defined as "divesting someone of human qualities". Not long ago it was discussed only with regard to wars, conflicts or genocide planned by a regime in order to annihilate minorities which didn't match the vision of a certain state order. In 1976 Kelman described this phenomena "as a perception of victims that weakens the victimizers' normal restraints on violent behaviour". ${ }^{3}$ Nevertheless, as exposed by the new research dehumanisation may have not only blatant but also subtle forms such as infra-humanisation (i.e., divesting of secondary emotions), ${ }^{4}$ mechanistic dehumanisation (divesting of human nature), ${ }^{5}$ dementalization ${ }^{6}$ divesting of the mental propertie ${ }^{7}$ or lacking human potentials. ${ }^{8}$ It often happens unwittingly between groups and individuals

3 N. Haslam, S. Loughnan, Dehumanization and Infrahumanization, "Annual Review of Psychology" 2014, no. 65 , p. 401.

4 J.-Ph. Leyens, M.P. Paladino, R. Rodriguez-Torres, S. Demoulin, A. Rodriguez-Perez, R. Gaunt, The emotional side of prejudice: The attribution of secondary emotions to ingroups and outgroups, "Personality and Social Psychology Review" 2000, no. 4, pp. 186-197; J.-Ph. Leyens, B. Cortes, S. Demoulin, J.F. Dovidio, M.P. Paladino, A. Rodriguez-Perez, R. Rodriguez-Torres, J. Vaes, Emotional prejudice, essentialism, and nationalism: The 2002 Tajfel lecture, "European Journal of Social Psychology" 2003, no. 33, pp. 703-717; J.-Ph. Leyens, S. Demoulin, J. Vaes, R. Gaunt, M.P. Paladino, Infra-humanization: The wall of group differences, "Social Issues and Policy Review" 2007, no. 1(1), pp. 139-172.

5 N. Haslam, Dehumanization: An integrative review, "Personality and Social Psychology Review" 2006, no. 10, pp. 252-264.

6 M.N. Kozak, A.A. Marsh, D.M. Wegner, What Do I Think You Are Doing? Action Identification and Mind Attribution, "Journal of Personality and Social Psychology" 2006, no. 90(4), pp. 543-555.

7 C.K. Morewedge, J. Presston, D.M. Wegner, Timescale Bias in the Attribution of Mind, "Journal of Personality and Social Psychology" 2007, no. 93(1), pp. 1-11.

8 M. Tarnowska, P. Sławuta, M. Kofta, Procesy dehumanizowania ,obcych”. Mechanizmy i funkcje, [in:] Poza stereotypy. Dehumanizacja i esencjalizm w postrzeganiu grup społecznych, eds. M. Drogosz, M. Bilewicz, M. Kofta, Warszawa 2012, pp. 131-165. 
hence remains undetected and poses a threat. What is more, it does not require the intergroup conflict to occur. ${ }^{9}$ The consequences of this process are various: the reduced empathy and the increase in antisocial behaviour, distorted moral judgement regarding others..$^{10}$ According to Leyens ${ }^{11}$ and Bandura ${ }^{12}$ to face the subtle forms of dehumanisation we should put more stress on similarities between people and on the so called universal values. However, these suggestions are rather blurred and pass by the whole critique on universalism voiced by Edward Said and many others. ${ }^{13}$ Aren't the universal values simply Western values which are globally imposed on the rest of the world? In his recent book Can Non-Europeans Think? Hamid Dabashi suggests that while the representatives of non-European worlds were compelled "to learn the language and culture of colonial interlocutors", these "interlocutors have never any reason to reciprocate" and "they became provincial in their assumptions of universality". ${ }^{14}$ Notably, Dabashi does not reject the idea of universalism but rather stresses that the content of universalism is narrowed to the self-reproducing European heritage of thoughts and images.

Taking the above-mentioned into account, in my article I would like to offer a more detailed approach to the possible ways of humanisation of the so called others by the means of aesthetic, literature and literary studies. I argue that the literature which represents different cultures and social groups may provide us with a wider, not only Western understanding of universal values and therefore offers a unique tool to humanise others and to enrich our social imaginary. This, however, requires an approach to the literary studies that should embark on emphasizing and discussing certain philosophical aspects of literature that I will refer to throughout this article following Rudolf Steiner, ${ }^{15}$ Martha Nussbaum ${ }^{16}$ and Lawrence Hinman' ${ }^{17}$ ideas. In the last section of my paper I will refer to my own experience of reading and studying Kurdish literature.

9 J.-Ph. Leyens et al., Infra-humanization..., p. 151.

${ }^{10}$ N. Haslam, S. Loughnan, op. cit., pp. 414-416; M. Bilewicz, Funkcjonalna dehumanizacja. Studium odczłowieczania ofiar i grup uciskanych, [in:] Poza stereotypy..., op. cit., p. 211-213.

${ }^{11}$ J.-Ph. Leyens et al., Infra-humanization..., p. 160.

${ }^{12}$ A. Bandura, Selective Moral Disengagement in the Exercise of Moral Agency, "Journal of Moral Education" 2002, no. 31(2), p. 108.

${ }_{13}$ B.M. Scherer, Edward Said's Universalism. The Perspective of the Margins, 2014, journeyofideasacross.hkw.de/out-of-academia-in-places/bernd-m-scherer.html (access: 1.04.2019).

${ }^{14}$ H. Dabashi, Can The Non-European Think?, London 2015, p. 5.

${ }_{15}$ R. Steiner, Filozofia Wolności (Die Philosophie der Freiheit), trans. J. Prokopiuk, Warszawa 1987.

${ }^{16}$ M.C. Nussbaum, Love's Knowledge. Esseys on Philosophy and Literature, New York-Oxford 1990.

${ }^{17}$ L.M. Hinman, The Role of Imagination in The Moral Life, "Journal of Professional and Applied Ethics" 2007, no. 9(2), pp. 14-20. 


\section{Our More and More Clever Brains and the Discrete Harm They Bring to Us}

In 1972 the famous Spanish film director Luis Bunuel directed a movie entitled The Discreet Charm of the Bourgeoisie where he mocked the rituals and manners of the elegant middle class showing what their sophisticated behaviour conceals is actually still of an animal nature. However, in light of the recent socio psychological studies, it is also possible to interpret Bunuel's work in a different way by suggesting that the sophisticated parts of our modern cultures trigger many dark phenomena and thus instead of being helpful become the growing obstacle in bringing people together. The infra-humanisation and other subtle forms of dehumanisation can be consider the dark outcome of our advanced modernity which consists of many intertwined layers of meanings and forms of expression that are conveyed in a constantly renewing style. They somehow resemble the multi-skinned onion from Szymborska's poem that I have quoted above, which we endlessly peel to find something new and valuable. The complexity of the modern world and its lust for innovation impose a demand for development and foster a concept of humanness which relies on certain competences connected with mind, intelligence, sentiments and the level of education. Though, as mentioned above, the subtle forms of dehumanisation have been defined with the help of many different notions and as a result of slightly different approaches and experiments, what they all have in common is their deep dependence on culture, language, forms of expression and education.

Infra-humanisation is a process detected in the scope of the recent socio psychological research ${ }^{18}$ and results in considering our ingroup as fully human and the outgroup as less human. It means divesting others of "uniquely human qualities", the so called "sentiments" or "secondary emotions". This process was revealed in many studies as the lower level of attribution of such qualities to the members of an outgroup. According to Leyens, ${ }^{19}$ the phenomena differs from dehumanisation which is usually understood as "the total divesting of human qualities". "Secondary emotions" or ,uniquely human qualities”, such as shame, sensitivity, love and indignation form later in life through the process of learning and socializing. In contrast to primary emotions, that we share with animals, they depend on other social variables, such as development of morality or cognitive capacities. They are considered culture-specific, and sometimes vary between cultures. Furthermore, they are cognitive constructs and rely on "the interpretation of the situation", and not just on "the situation itself". ${ }^{20}$

What is interesting, the process of the denying happens not only in case of positive secondary emotions (for instance love and sensitivity) but also in case of the negative ones (shame or indignation). In other words the members of the

${ }_{18}$ J.-Ph. Leyens et al., The emotional side of prejudice...; J.-Ph. Leyens et al., Emotional prejudice...; J.-Ph. Leyens et al., Infra-humanization ...; S. Demoulin, J.-Ph. Leyens, M.P. Paladino, R. Rodriguez-Torres, A. Rodriguez-Perez, J.F. Dovidio, Dimensions of "uniquely and "non-uniquely" human emotions, "Cognition and Emotion" 2004, no. 18(1), pp. 71-96.

19 J.-Ph. Leyens et al., Infra-humanization...

${ }^{20}$ S. Demoulin et al., op. cit., p. 75. 
outgroup are perceived as less prone to more sophisticated good and more sophisticated evil. Thus it is clear that others are repelled precisely because of not being "sophisticated" enough. Needless to stress that the understanding of the word "sophisticated" is always heavily linked to our particular social and cultural imaginary. The imaginary is often understood as unique and innate essence of a group that forms its unchangeable substance. Therefore, essentialism "is the belief that people are what they are by substance as opposed by the conviction that there are discontinuities in humanity". ${ }^{21}$ As stressed further by Leyens such a belief totally contradicts the idea that groups are in fact social constructions. In other words people see their cultural and social constructs as everlasting and natural. It means that we reproduce the meanings within our own worlds which are of course shaped by the languages we communicate with our ingroup. On the other hand we are rather reluctant to perceive the same "dignified and sophisticated essence" in the representatives of other cultures, whose imaginary we usually have limited access to because of not knowing their language and cultural context.

What is also important the infra-humanisation relies on the comparison between animal and human, ${ }^{22}$ which is usually evaluated in favour of the human, their intelligence and thus supremacy that have been entrenched in both religious and evolutionary worldview. Also the other frameworks in which the subtle forms of dehumanisation have been described such as "dementalization", "divesting of mental properties" or "lacking the human potentials" suggest that the power of mind and human capacities to develop brain potentials are crucial for our average grasp of humanity. It was shown by the research designed by Leyens:

To approach the humanity of groups' essence, we asked Spanish and French speaking Belgians to rank-order all the characteristics that they considered uniquely human. The consensus was substantial. In the first place, students cited intelligence or a related word (e.g., reasoning). In the second place, they cited a word associated with language (e.g., communication) or the word "sentiment" (or an exemplar of it). ${ }^{23}$

\section{Abstract Notions versus Imagined Reality}

As revealed in some studies on infra-humanisation, when the members of the outgroup directly expressed secondary emotions or human qualities in a message, it did little to humanise the outgroup by the ingroup. On the contrary, such direct reference to secondary emotions was treated as pushy, and the level of infra-humanisation became higher. ${ }^{24}$ This means, people are sensitive to the identity of

${ }^{21}$ J.-Ph. Leyens et al., Infra-humanization..., p. 142.

${ }^{22}$ N. Haslam, S. Loughnan, op. cit., p. 403.

$23 \mathrm{~J} .-\mathrm{Ph}$. Leyens et al., Infra-humanization..., p. 145.

${ }^{24}$ A.J.C. Cuddy, M.S. Rock, M.I. Norton, Aid in The Aftermath of Hurricane Katrina: Inferences of Secondary Emotions and Intergroup Helping, "Group Processes and Intergroup Relations" 2007, no. 10(1), pp. 107-118; M.J.A. Wohl, M. Hornsey, Sh.H. Bennett, Why Group Apologies Succeed and Fail: Intergroup Forgiveness and the Role of Primary and Secondary Emotions, "Journal of Personality and Social Psychology" 2012, no. 102(2), pp. 306-322; A. Demirdağ, Barı̧̧ Sürecinin Desteklenmesinde Insanliktan Uzaklaştırmanın Etkisi (unpublished master thesis), Ankara University, 2014, p. 69. 
the one who speaks to them, but also, to the way the information is presented. It suggests that the expression of abstract notions (secondary emotions, in this case), is not helpful by itself. Being suspicious about the members of the outgroup, we would not easily believe that they possess uniquely human qualities when they try to assure us about it. And this is precisely the point where the role of imagination and the cultural narratives such as literature or film can be grasped. It is because, as stressed by Rudolf Steiner the imagination is not an abstract but rather individualised concept. It fills the gap between the abstract ideas we have in our minds and observations we make by means of our senses. ${ }^{25}$ Martha Nussbaum suggested that literature should be considered a part of moral philosophy that helps us to see

the world's surprising variety, its complexity and mysteriousness, its flawed and imperfect beauty - that cannot be fully and adequately stated in the language of conventional philosophical prose, a style remarkably flat and lacking in wonder - but only in a language and in forms themselves more complex, more allusive, more attentive to particulars. ${ }^{26}$

This way, instead of abstract rules and notions we are offered sequences of descriptive words, sentences and images that can guide us into the inner world of the others which to Hinman is the foundation of morality and thus our understanding of humanness too. It is because such an insight can help us to grasp the "how" of the abstract humanness of others with whom we have rare or no direct contacts. ${ }^{27}$ Nussbaum affirms the role of perception and emotional response that can be developed by reading or watching and is underestimated in the solely intellectual reasoning:

Frequently a reliance on the powers of the intellect can actually become an impediment to true ethical perception, by impeding or undermining these responses. It frequently happens that theoretical people, proud of their intellectual abilities and confident in their possession of techniques for the solution of practical problems, are led by their theoretical commitments to become inattentive to the concrete responses of emotion and imagination that would be essential constituents of correct perception. ${ }^{28}$

\section{Dehumanisation as Divesting of Warmth and Vitality. The Healing Role of the Literary Access to Emotions}

However, the subtle forms of dehumanisation may be also defined otherwise. Haslam offered another framework suggesting that people can also be compared to inanimate objects (such as machines or robots) and thus denied the emotional warmth or vitality. He described this kind of dehumanisation as mechanistic dehumanisation or divesting of human nature. His research proved that in some cases the average concept of humanness may be more entrenched in a vision of a "sensible" and not necessarily "thoughtful" human being. The latter may also

\footnotetext{
25 R. Steiner, op. cit., p. 80.

${ }_{26}$ M.C. Nussbaum, op. cit., p. 3.

27 L.M. Hinman, op. cit., p. 17.

${ }_{28}$ M.C. Nussbaum, op. cit., p. 81.
} 
be associated with emotional coldness and inattentiveness. ${ }^{29}$ Nevertheless, these two abovementioned forms of subtle dehumanisation definitely complement each other and seem to rely on the different cultural patterns that are given priority to in the various social and cultural contexts we live in.

Reflecting on the Haslam's research results we may come to the conclusion that they can also be the reason why literature should be considered as an ally in coping with the subtle forms of dehumanisation. Nussbaum claimed that the access to emotions provided by literature and other forms of art, the state of being overwhelmed by emotions while reading, watching or simply contemplating a work of art, which was often regarded a liability, should be seen as an asset. It is because our feelings and impressions are the inseparable part of the knowledge we obtain from the surrounding world and - what is crucial - about our being and acting in this world. ${ }^{30}$ In other words, the process of reading offers us the possibility to jump into the shoes of others, to be submerged into their reality, their thoughts, feelings and sometimes into the different cultural contexts that explain the choices and actions they made. This way we can identify with others while reading and the identification itself is crucial for obtaining reliable knowledge and humanising others. Taking into account our own experiences and knowledge we may agree or disagree with the characters' worldview or choices which implies that what we actually achieve is not necessarily the favourable view of others. As already stressed above the infra-humanisation must be distinguished from simple favouritism. In the scope of the infra-humanising process we attribute to others less positive and negative qualities. ${ }^{31}$ Therefore, the humanising aspect of reading entails no need for becoming more favourable toward the characters. Moreover, the fictional world and human beings portrayed in literature are not the passive space left for readers' contemplation. They usually intermingle with our own thoughts and experience, hence what we actually deal with is a third reality that bridges the author's imagination with our own. The overlap is most probably the very humanising aspect of getting access to the worlds of others. As far as "our" imagination intermingle with "theirs" we can no longer totally separate "us" from "them". Voluntarily or not we become interconnected.

\section{Domino Effect of Dehumanisation. Hamid Dabashi and the Kurds}

The subtle forms of dehumanisation seem ubiquitous and therefore the theoretical framework they offer to discuss many modern phenomena may be very useful these days. As already highlighted, they correspond with many modern theories for instance postcolonialism. Notably, the socio psychological approaches are not restricted to any particular historical experiences which although individualise the topic but at the same time narrows it to some space and time not allowing many researchers to see the many diverse and ambiguous dimensions of colonial

\footnotetext{
29 N. Haslam, op. cit.

${ }^{30}$ M.C. Nussbaum, op. cit., pp. 261-285.

31 J.-Ph. Leyens et al., Infra-humanization ..., p. 146.
} 
subordination. A good example of such a postcolonial paradox is the case of Hamid Dabashi and his view on the Kurds. As mentioned above in his book Hamid Dabashi explored many different discourses within which non-European thinkers are marginalised. We read:

I am $[\ldots]$ interested in the curious question of whether or not European philosophers can actually read something [from non-European authors - JB] and learn from it - rather than assimilate it back into what they already know. ${ }^{32}$

Dabashi's aim is to highlight the still existing wall that does not allow the non-Europeans to be perceived as something more than the object of neo-colonizing policy. Not entering into any polemic with Dabashi on this subject I wish to emphasize that in light of the studies on the subtle forms of dehumanisation, denying the mental properties of the members of an outgroup exceeds the limits of Western-Eastern or European-Non-European polarisation. Though it is clear that all forms of dehumanisation, both blatant and subtle, have a lot in common with the power of one group over another, its higher status or the threat it faces, ${ }^{33}$ it is clear that not only the "powerful Europeans or Americans" are prone to dehumanising practises. The research by Bain and colleagues (2009) indicated for example that "Chinese associated white faces less strongly with uniquely human traits than East Asian faces". ${ }^{34}$ The fact of possessing power or higher status is not only the feature of European or American colonialism but rather the ubiquitous and probably eternal human propensity. Therefore, it is justifiable to point out Hamid Dabashi's selectiveness in referring to non-European intellectuals and artists. Though we can find among them people of many different backgrounds such as Walter Mignolo, Aditya Nigam, ${ }^{35}$ Elia Suleiman ${ }^{36}$ or Akiro Kurosawa ${ }^{37}$ we cannot discover any particular reference to the Kurdish intellectuals. Hence, we can say quoting from Dabashi himself, that he "did not read anything" written by the Kurdish authors or simply "assimilated it to what he already knows". Therefore, in spite of his critical approach to the Western orientalism and neo-orientalism he also reproduces the dehumanising neglect and marginalisation. I chose the Kurdish example, not accidentally of course. In Iran the Kurds are still under the pressure of the government's restrictive policy and face the danger of being assimilated into the Farsi speaking world. Akin to Muslims being misrepresented in the West, the Kurds are misrepresented in the four Middle Eastern countries they live in. They are at best associated with tribal customs and traditional culture and most of the so called public opinion in Turkey, Iran, Syria or even Iraq is completely unaware that there is any modern intellectual production in Kurdish language. And even though Dabashi, as an Iranian-American professor cannot be associated with the Iranian regime and his arguments against the European neoorientalism are justified, he would be much more convincing and trustworthy as

\footnotetext{
32 H. Dabashi, op. cit., p. 5.

33 N. Haslam, S. Loughnan, op. cit., pp. 413-415; M. Bilewicz, op. cit., pp. 215-217.

34 N. Haslam, S. Loughnan, op. cit., p. 408.

35 H. Dabashi, op. cit., p. 5.

36 Ibidem, p. 128.

37 Ibidem, p. 153.
} 
a postcolonial academic, if he wished to appreciate the Kurdish authors and refer critically to the failures of his own intellectual background too. Instead, though he once briefly mentions "the condescending attitude of self-proclaimed Persians toward the minorities such as Kurds, Azeris, Baluch", ${ }^{38}$ at the same time he denies the Kurds the right to self-determination suggesting that they should "abandon their dream of unified Kurdistan". ${ }^{39}$ In other words his approach to the Kurdish question is similar to what he criticizes in the case of Western policy toward the Middle East. One may aptly stress that it is not Mr Dabashi's duty to suggest what the Kurds should abandon. Also, as pointed out by Barzoo Eliassi in the book Iran: A people interrupted, Dabashi "rhetorically penalizes Kurdish claims for creating a nation-state" 40 and "implicitly asks the Kurds to quell their dissent and avoid contestation of the Persian rule that discriminates non-Persian groups in Iran". ${ }^{41}$ Hence, it is clear that Dabashi's image of the Kurds is also distorted due to his cultural and national background that claims power over this group. This example indicates well that while we usually have no problems with criticising powerful "them" for "their" dehumanising approaches to "us", we are less keen to see our own dehumanising approaches toward those whom we believe to be somehow lower on the imagined ladder of humanness. It is clear from the various studies on dehumanisation that such a hierarchical scale may consist of many different sets of beings, not only of national, ethnic or religious groups but also of women, ${ }^{42}$ animals ${ }^{43}$ or children. Therefore, what should be actually promoted is a kind of sensitivity, self-awareness or self-criticism that would be able to detect not only our role as objects of dehumanising policy of others but also as its subjects and creators.

\section{Why the Voice of Kurdish Culture Matters}

I have come to Kurdish studies from a very unusual field. I graduated as a specialist on Russian literature and only after meeting Kurds in Moscow in 2001 I became interested in their identity and cultural production. Initially, I had no idea about any Oriental studies let alone the notorious orientalism. Nevertheless, while comparing Russian or Polish literary output with the Kurdish one, I belittled it at first. In light of the abovementioned theories I can say that I infra-humanised the Kurds denying them their uniquely human qualities. "They are nice people but they do not seem to be able to offer me anything in terms of my intellectual development" - that is what I thought. However, being the child of a Polish-Tatar family I was aware that the attitude I have toward the Kurds is pretty much the

38 Ibidem, p. 211.

39 Ibidem, p. 192.

40 B. Eliassi, Contesting Kurdish Identities in Sweden, London-New York 2013; idem, Leftist intellectuals and the Kurds: The cases of Edward Said, Hamid Dabashi and Tariq Ali, 2013, http://www. rudaw.net/english/yourrudaw-26062013000624 (access: 7.02.2017).

41 Ibidem.

42 N. Haslam, S. Loughnan, op. cit., p. 408.

43 M. Bilewicz, op. cit., p. 213; N. Haslam, S. Loughnan, op. cit., p. 411. 
same that I face as a person connected with a Tatar Muslim background in Poland, or as a Polish or Tatar in Russia. I used my experiences to look critically at my dehumanising approach. Furthermore, I trusted my intuition which ignited my interest to learn Kurdish language and know the Kurds better before jumping into any conclusions or judgements. Today, I believe that developing Kurdish studies, and studies on Kurdish culture in particular is of crucial importance not only to enrich our endless stocks of knowledge collected on the dusty academic shelves but also to make the world a better place. As stressed by Donna Hicks in her insightful book on the meaning and role of dignity in resolving conflicts, it is because:

Treating others well and recognizing their humanity (both their worth and their vulnerability) have incalculable benefits everywhere that human beings cluster: in families, communities, the workplace and nations. Honouring people's dignity is the easiest and fastest way to bring out the best in them. The opposite is equally true. Treating people as if they don't matter creates destructive emotional upheavals. ${ }^{44}$

Therefore, our attention to the Kurdish intellectual and artistic production (as well as to the production of all other marginalized and persecuted groups) may help us all to recognise their dignity and simultaneously to aid them in establishing channels of communication with those who neglect or suppress them in the countries they live in. It does not necessarily mean to support their - as I often hear - "separatist claims that may cause further troubles in the Middle East" (though I personally think these claims are fully justified). First of all, it means to assist the Kurds in overcoming the dangerous infra-humanisation and deliberated dehumanisation they face and in saving from extinction their language and culture. Their thoughts and art can enrich our "ethnocentric" understanding of human dignity in exchange.

However, there is still more to be said about the importance of the Kurdish culture for the contemporary Middle East. As many other groups the Kurds happened to be both the victims (most often) and the oppressors in the curse of the $20^{\text {th }}$ and $21^{\text {st }}$ centuries' political and social turbulences. Yet in their narratives we can find a special self-awareness that I have referred to above which does not allow the Kurds simply to blame the others for what happened to them and to other inhabitants of Kurdistan. In other words many of the Kurdish intellectuals use their experience and become sensitive to the misery the Kurds caused to others and therefore they seem to avoid the trap that snared even Hamid Dabashi.

Let me in the end offer the reader an analysis of a short story written by Mehmet Dicle the young Kurdish writer from Bakur (North Kurdistan/Turkey) currently living and working in Istanbul. In his short story trilogy Asus $^{45}$ (2013), $\operatorname{Nara}^{46}$ (2010) and $\mathrm{Ta}^{47}$ (2013) he created the fictitious land of Asûs where the Kurdish past and present intermingle. In one of his short stories entitled Kuça filan

${ }^{44}$ D. Hicks, Dignity, Its Essential Role in Resolving Conflicts, New Haven-London 2011, p. 67.

${ }^{45}$ M. Dicle, Asûs, Istanbul 2013.

${ }^{46}$ M. Dicle, Nara, Istanbul 2010.

${ }^{47}$ M. Dicle, Ta, Istanbul 2013. 
(The street of Christians ${ }^{48}$ ) Dicle intertwined many images and topics. First of all, we may interpret this story in a biographical context and point out the writer's wish to settle accounts with childhood fears, of which his father-mullah was an inseparable part. Moreover, the short story exposes the unquestionable cruelty of a small boy who, having been forced to abandon his childish toys and study in the mosque, derives more and more pleasure from the "bloody games". ${ }^{49}$ Along with other children he tortures and kills animals, refining his malevolent skills. More than that, we deal with the repressed memory of Asûs inhabitants who avoid remembering the Armenians' tragedy. Dicle exposes and discusses the Kurdish responsibility for what happened to the Armenians in 1915 (p. 80). ${ }^{50}$ The bones of Armenians come up every spring along with the overflow of water. And though we are told about the Turkish army which is waiting in the background, hunting for those hidden in the mountains and "howling like wolves during the winter nights". ${ }^{51}$ Dicle does not end up blaming the Turks for all that happened. Kurdish children make flour from Armenian bones, and those who leave the mosque lower their eyes and say nothing to stop them. The past is suppressed and suffocated, which adds to the cruelty of Asûs. One day Asûs inhabitants change into swallows and the boy becomes obsessed with killing all the swallows' chicks "to prevent their grandchildren from playing with human bones". ${ }^{52}$ But at the end of the story we are confronted with one very particular image, which shocks and delights us, at the same time bringing moral awareness and hope for the future. On his way to the mosque, depressed by the fact that his friend was bitten by a snake, the boy kills a white kitten: "the snow-white ball looked as if it had fallen into the bowl of dims": 53

${ }^{48}$ The story Kuça Fîlan was published in the Nara collection of short stories (pp. 77-84). The Kurdish (Kurmanji) word kuçe can be translated as wynd or backstreet too. This analysis was first published in the bulletin "Fritillaria Kurdica. Bulletin of Kurdish Studies" (no. 15) as part of my introduction to the Polish translation of four Dicle's short stories.

${ }^{49}$ M. Dicle, Nara, p. 79.

${ }^{50}$ It should be stressed that Mehmet Dicle is not the first Kurdish writer who speaks of the Armenian genocide. This topic was probably first referred to by Yaşar Kemal who was a Kurdish born author writing in Turkish (Rohat, Yaşar Kemal'ın Yapıtlarında Kürt Gerçeği, Istanbul 1992, pp. 42-43). As stressed by Çelik and Öpengin, the events and consequences of 1915 started to be more widely discussed in Kurdish literature in recent decades. It was made possible due to the growing interest in exploring the repressed memory of 1915 visible in Turkey in the first decade of 21 st century. Çelik and Öpengin pointed out eight novels: Kilama Pepûgî (2000) by Deniz Gündüz written in Zazaki dialect, Mehdi Zana's Ah Dayê (O Mom!, 2005), Sabri Akbel's Evina Pinhan (Hidden Love, 2006), Hesenê Metê's Gotinên gunehkar (Sinful words, 2007), Yaqob Tîlermenî's Bavfileh (Proselyte, 2009), Îrfan Amîda's Pêşangeha Sûretan (Exhibition of Faces, 2011), Eyub Guven's Guhar (Earring, 2011), Mehmet Deviren's Kortika Filehan (The Well of Christians, 2013), and five short story collections: Ferat Dilgeş's Dilşa (2003), Amed Çeko Jiyan's Varjabed (2010), M Elî Kut's Mehkûm (Convict, 2002), Umer Farûq Ersoz's Berenge (2013), Mehmet Dicle's Ta (2013). A. Çelik, E. Öpengin, The Armenian Genocide in the Kurdish Novel: Restructuring Identity Through Collective Memory, "European Journal of Turkish Studies", ejts.revues.org/5291 (access: 22.04.2019). Also Nara by Mehmed Dicle and İdam (2003) by Ruşen Arslan should also be mentioned though the second collection was written in Turkish.

${ }^{51}$ M. Dicle, Nara, p. 78.

52 Ibidem, p. 81.

${ }^{53}$ Dims is the red colour molasses-like syrup from grapes. 
I threw my stone toward the place I heard the voice from, with the blindness of a hunter. / While my stone was still in the air, I glanced at the spot where I had heard the voice from and I regretted what I had done. The small kitten. White. The ball of snow. I wanted my stone to become cold, to fall to the ground or return and hit my head. / But my aim is never wide of the park. I am famous amongst my friends for it. And this time it was precise too. I was weak at the knees as if my legs had been beaten with a stick. The baby cat. The snow-white ball looked as if it had fallen into a bowl of dims. It became red. Trembling. My heart shattered. ${ }^{54}$

The moment of killing the kitten shocks us not just because of the cruelty of the small boy, but thanks to the perversity of the description, which is very beautiful. First of all, we are reminded about the beauty of evil which keeps fascinating us. However, if we read this piece carefully we will realise that this is not the case. The innocence is still present, so perhaps all is not lost. Although the boy wanted to kill, which is why he picked up and threw the stone, he didn't see the beauty of the kitten. And when he realized it, he did repent. The feeling of guilt made him abandon the place, the Quran (which "landed in the puddle on the Christian street" ${ }^{\prime 5}$ ) and finally caused his illness.

The piece quoted above contains many images which intertwine: we see the boy picking up the stone, the stone in the air before it will hit its target, the kitten, the ball of snow, the bowl with grape syrup, the red colour, the white colour, the stick hitting the boy's knees, the trembling of the kitten's body. We are also informed that all this happened on the Christian street where the boy wanted to play with the (Armenian) bones but didn't find any. And this is where his Quran fell into the puddle. Moreover, after killing the kitten, the boy's repentance and illness bring some changes into his and his family's life. For the first time he realizes that he misses his father's warmth and that he wishes to hug him. The father, also "for the first time" listens to his wife's words and does not scold the boy. The boy abandons his education in the mosque and his father does not prevent him from doing so. ${ }^{56}$

Therefore, the episode must be interpreted in a broader sense as bringing together all the plot lines mentioned in the story. It inevitably alludes to the Armenian genocide, raising the hope that recalling the beauty of the Armenians and their culture can be helpful in realizing the guilt and evoking repentance. But something still remains to be hidden in the sequence of images of a boy, his stonelike cruelty and the beauty of the kitten. The kitten's beauty in a way "humanises" the animal in the eyes of the boy and therefore makes it more difficult to kill it. But we still need to ask why it happened only then and not before, and thus what are the prerequisites for one to see the beauty and value of the other. Perhaps it was the boy's poignant feeling of loneliness on his way to the mosque and maybe his friend's fatal illness that made him more aware of the loss and suffering? Or perhaps it was the charm of the shaded street itself? Despite all the doubts and dark experiences of the $20^{\text {th }}$ and $21^{\text {st }}$ centuries, Mehmet Dicle's short story reveals

\footnotetext{
${ }^{54}$ M. Dicle, Nara, p. 82. Translation from Kurmanji Kurdish into English was done by the author.

${ }_{55}$ Ibidem, p. 83.

56 Ibidem, pp. 83-84.
} 
the power of beauty. It is thanks to our ability to recognise the beauty of the other that any kind of mistreatment becomes inadequate and horrifying.

Thank you dear Professor Anna Krasnowolska for your contribution and trust in literary studies, for enabling us all to discover new fields of research in our Kraków Iranian Studies Department.

\section{Bibliography}

Bandura A., Selective Moral Disengagement in the Exercise of Moral Agency, "Journal of Moral Education" 2002, no. 31(2), pp. 101-119.

Bilewicz M., Funkcjonalna dehumanizacja. Studium odczłowieczania ofiar i grup uciskanych, [in:] Poza stereotypy. Dehumanizacja i esencjalizm w postrzeganiu grup społecznych, eds. M. Drogosz, M. Bilewicz, M. Kofta, Warszawa 2012, pp. 211-226 .

Bocheńska J., Mehmet Dicle and His Iridescent Images from Asûs, "Fritillaria Kurdica. Bulletin of Kurdish Studies" 2016, no. 15, pp. 4-21.

Bocheńska J., Humanising The Actors And Working Through The Conflict: The Role of Kurdish Literature And Culture In The Reconciliation Process in Turkey, "International Journal of Conflict And Violence" 2018, no. 12, pp. 1-16.

Cuddy A.J.C., Rock M.S., Norton M.I., Aid in The Aftermath of Hurricane Katrina: Inferences of Secondary Emotions and Intergroup Helping, "Group Processes and Intergroup Relations" 2007, no. 10(1), pp. 107-118.

Çelik A., Öpengin E., The Armenian Genocide in the Kurdish Novel: Restructuring Identity Through Collective Memory, "European Journal of Turkish Studies", http://ejts.revues.org/5291 (access: 22.04.2019).

Dabashi H., Can The Non-European Think?, London 2015.

Demirdağ A., Barış Sürecinin Desteklenmesinde Insanliktan Uzaklaştırmanın Etkisi (unpublished master thesis), Ankara University, 2014.

Demoulin S., Leyens J.-Ph., Paladino M.P., Rodriguez-Torres R., Rodriguez-Perez A., Dovidio J.F., Dimensions of "Uniquely and "Non-uniquely" Human Emotions, "Cognition and Emotion" 2004, no. 18(1), pp. 71-96.

Dicle M., Nara, Istanbul 2010.

Dicle M., Asûs, Istanbul 2013.

Dicle M., Ta, Istanbul 2013.

Eliassi B., Contesting Kurdish Identities in Sweden, London-New York, 2013.

Eliassi B., Leftist Intellectuals and the Kurds: The cases of Edward Said, Hamid Dabashi and Tariq Ali, 2013, http://www.rudaw.net/english/yourrudaw-26062013000624 (access: 7.02.2017).

Haslam N., Dehumanization: An Integrative Review, "Personality and Social Psychology Review" 2006, no. 10, pp. 252-264.

Haslam N., Loughnan S., Dehumanization and Infrahumanization, "Annual Review of Psychology" 2014, no. 65, pp. 399-423.

Hicks D., Dignity, Its Essential Role in Resolving Conflicts, New Haven-London 2011.

Hinman L.M., The Role of Imagination in The Moral Life, "Journal of Professional and Applied Ethics" 2007, no. 9(2), pp. 14-20. 
Kozak M.N., Marsh A.A., Wegner D.N., What Do I Think You Are Doing? Action Identification and Mind Attribution, "Journal of Personality and Social Psychology" 2006, no. 90(4), pp. 543-555.

Leyens J.-Ph., Cortes B., Demoulin S., Dovidio J.F., Paladino M.P., Rodriguez-Perez A., Rodriguez-Torres R., Vaes J., Emotional Prejudice, Essentialism, and Nationalism: The 2002 Tajfel Lecture, "European Journal of Social Psychology" 2003, no. 33, pp. 703-717.

Leyens J-Ph., Demoulin S., Vaes J., Gaunt R., Paladino M.P., Infra-humanization: The Wall of Group Differences, "Social Issues and Policy Review” 2007, no. 1(1), pp. 139-172.

Leyens J.-Ph., Paladino M.P., Rodriguez-Torres R., Demoulin S., Rodriguez-Perez A., Gaunt R., The Emotional Side of Prejudice: The Attribution of Secondary Emotions to Ingroups and Outgroups, "Personality and Social Psychology Review" 2000, no. 4, pp. 186-197.

Morewedge C.K., Presston J., Wegner D.M., Timescale Bias in the Attribution of Mind, "Journal of Personality and Social Psychology" 2007, no. 93, 1, pp. 1-11.

Nussbaum M.C., Love's Knowledge. Esseys on Philosophy and Literature, New YorkOxford 1990.

Rohat, Yaşar Kemal'ın Yapitlarında Kürt Gerçeği, Istanbul 1992.

Scherer B.M., Edward Said's Universalism. The Perspective of the Margins, 2014, http://journeyofideasacross.hkw.de/out-of-academia-in-places/bernd-m-scherer. html (access: 1.06.2016).

Steiner R., Filozofia Wolności (Die Philosophie der Freiheit), trans. by J. Prokopiuk, Warszawa 1987.

Szymborska W., The Onion, trans. by S. Barańczak, C. Cavanagh, http://www.szymborska.org.pl/the-onion.html (access: 30.04.2019).

Tarnowska M., Sławuta P., Kofta M., Procesy dehumanizowania ,obcych”. Mechanizmy i funkcje, [in:] Poza stereotypy. Dehumanizacja i esencjalizm w postrzeganiu grup społecznych, eds. M. Drogosz, M. Bilewicz, M. Kofta, Warszawa 2012, pp. 131-165.

Wohl M.A., Hornsey M., Bennett Sh.H., Why Group Apologies Succeed and Fail: Intergroup Forgiveness and the Role of Primary and Secondary Emotions, "Journal of Personality and Social Psychology" 2012, no. 102(2), pp. 306-322. 